\title{
LVII. Account of the iron mine at Haytor, in Devonshire
}

\section{J.T. Kingston Esq.}

To cite this article: J.T. Kingston Esq. (1828) LVII. Account of the iron mine at Haytor, in Devonshire, Philosophical Magazine Series 2, 3:17, 359-365, DOI: 10.1080/14786442808674664

To link to this article: http://dx.doi.org/10.1080/14786442808674664

里 Published online: 10 Jul 2009.

Submit your article to this journal $₫$

Џ Article views: 3

Q View related articles $₫$ 
fortresses, before breaches, and to defend bridges and passes, wherever an enemy is likely to attempt a surprise. They might also be placed around field works likely to be attempted by assault. They would require to be sunk a little in the ground, so that the splinters of one might not derange those near to it, and covered lightly over to protect them from wet, and also to conceal their position from an enemy.

This principle might also be applied to the firing of artillery by percussion; more particularly at sea, where the roll of the vessel presents so great an obstacle to accuracy of fire. In that case, the vent of the gun would require to be placed a little on one side, to be clear of the'line of sight, and a hole drilled through the spring opposite the vent, to allow the flash from it to escape. The support of the spring would, of course, be pulled away by a string, so that the man who laid the gun might also fire it.

LVII. Account of the Iron Mine at Haytor, in Devonshire. By J. T. Kingston, Esq.

To the Editors of the Philosophical Magazine and Annals. Gentlemen,

A MINERAL production discovered at the Haytor Iron A Mine having formed the subject of two or three papers in your valuable Journal *, you may perhaps consider a description of the mine itself not unworthy of occupying a page or two of your next Number; especially as it is, at least to the best of my knowledge, the only one of the kind hitherto discovered in this island, and as such, of some importance in a geological as well as in an ceconomical point of view $\dagger$.

The lode, to the depth at present explored, is a very regularly stratified one, of oxidulated iron ore and argillaceous schist, in alternate beds; and is situated on the edge of the granite district, near the base of the Haytor rocks. 'The hill, on the brow of which, near the centre, it crops out, is immediately incumbent on the granite; its principal slope is gradual and towards the East, the sides having a more precipitous descent to the North and South. It consists chiefly of micaceous passing into clay schist, and of trap $\ddagger$ (provincially

* See Phil. Mag. and Annals, N.S. vol. i. p. 38, 40, 43.

+ Some particulars of the vein of ore worked in this mine, will be found in Mr. W. Phillips's paper on Haytorite, which is the first of the communications just referred-to.-EDIT.

$\ddagger$ Mr. W. Phillips, we observe, has stated that this substance appears to be siliceous schist.-EDIr. 
termed Ironstone) of a compact basaltic texture, and great specific gravity; and mostly containing a proportion of iron-ore, which occasionally runs in distinct threads and patches through small portions of it. The lode occurs in the clay schist, and the direction of its strata is nearly North-west and Southeast, underlying to the North-east at an angle of $22^{\circ}$ or $23^{\circ}$ only for the first few feet from the surface; but below this the dip is very regular at an angle of $45^{\circ}$. It happens to be situated in two distinct estates, which a road, intersecting the lode near the centre, divides; and having hitherto been worked separately, a complete wall from the surface to the depth explored, has been left, of which the following is an accurate section and measurement; the measurement is taken at the depth indicated by the dotted line, which is also the direction of the level driven from the back of the lode.

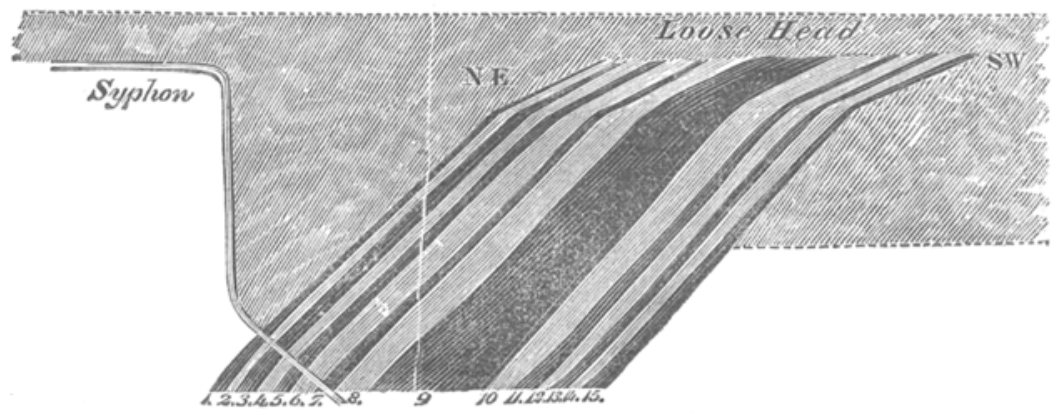

\begin{tabular}{|c|c|c|c|c|}
\hline \multicolumn{5}{|c|}{ Thickness of Beds. } \\
\hline No. & \multicolumn{2}{|c|}{ Ore. } & \multicolumn{2}{|c|}{ Schist. } \\
\hline I & $1^{\mathrm{ft}}$ & $0^{\text {in. }}$ & & \\
\hline 2 & & & & $6^{\text {in. }}$ \\
\hline 3 & 1 & 3 & & \\
\hline 4 & & & 1 & 3 \\
\hline 5 & 1 & 3 & & \\
\hline 6 & & & 2 & 0 \\
\hline 7 & 0 & 6 & & \\
\hline 8 & & & 2 & 6 \\
\hline 9 & 8 & 0 & & \\
\hline 10 & & & 3 & 6 \\
\hline 11 & 2 & 0 & & \\
\hline 12 & & & 1 & 3 \\
\hline 13 & 0 & 6 & & \\
\hline 14 & & & 1 & 0 \\
\hline 15 & 1 & 6 & & \\
\hline
\end{tabular}

16 feet ore.

12 feet schist.

28 feet whole width of lode. 
By this it will be seen, that the central bed is of iron-ore, and considerably the largest; whilst the other alternating beds of schist and ore are disposed above and below it in a tolerably regular relative proportion. The schist having a tendency to contract in width, as the depth increases, and the ore to approximate each way towards the central bed, into which, the obvious probability is, that the other beds, at a greater depth, run; but whether this is the case, or whether, if they do so, the central bed is proportionally increased, must of course remain uncertain, until a level is driven, which I understand it is proposed to drive from the northern ravine, and which would cut the lode at about 150 feet perpendicularly below the surface. Permanent springs rise at the depth of a few feet, the water from which is carried off by a syphon bent over the northern slope of the hill. A level driven from the back of the lode, at the depth of about 20 feet from the surface, through schist, in a south-west direction, intersected, about 30 feet from its commencement, another small bed of ore, about $3 \frac{1}{2}$ feet in width, in which a large proportion of iron-pyrites is disseminated, the dip being the same as that of the principal lode, with which, however, it does not seem to be connected; the latter being included in a well-defined manner, within the limits pointed out by the above section, from which the width will be seen to be about 28 feet. The length, of course, is not capable of being so accurately defined : from the part where the section was taken on the western side, the traces are observable on to the granite, a distance of 230 yards, which they do not enter, but are conformable along its edge for some distance in a northerly direction; and on the eastern or lower side, it has been traced for the distance of 250 yards, down to a compact stratum of trap*, blended with garnet and actinolite, against which the traces appear to have been hove in a zigzag curved manner, and to dip under it. The length however of the beds containing ore of a quality available for smelting, does not (at least to the depth at present excavated) exceed 150 yards.

The surface along the whole line of the lode, as well as on each side of it, is apparently regular and undisturbed, and consists of a loose head of flat schistose stones and fragments, and the earthy mould arising from their decomposition, to the depth of five or six feet. In this head, at either end, along the line of the lode, bunches of manganese contaminated by iron occur. Near the central part of the lode an old sinking was discovered to the depth of 42 feet on one single bed of the

\footnotetext{
* See former note on this substance--EDrr.
}

New Series. Vol. 3. No. 17. May 1828. 
ore. There remain no records in the neighbourhood, as to when or for what purpose this excavation was made; but the probability is, that it was mistaken for tin, old stream-works for obtaining which abound in the neighbourhood. Only a small portion (if any) appears to have been carried off; as the chief part was left in heaps, and strewed on the surface to the extent of two or three acres immediately round, and which in fact led to the discovery of the mine, and remained unaccounted for some time after.

The chief part of the ore is of a compact texture, but portions of it, especially on approaching the surface, are coarsely granular; more or less perfectly formed crystals, loosely aggregated, are also frequent. The per-centage of iron it contains varies from 40 to 70 (the average probably of what has hitherto been worked yielding in the large way about 50); some of the richer specimens are actively magnetic; when pulverized, the ore is brownish black, and passively magnetic. It occurs also mixed with sulphur and with arsenic, in coarsely granular masses. Spathose carbonate of iron and also ironpyrites are met with; the latter, either in decomposing granular concretions, radiated, in more or less perfect cubic crystals, and in small spangles disseminated through the coarser granular ore. Copper-pyrites and arsenical pyrites also occur, the former very sparingly.

The other mineral specimens discovered in the faults and cavities of the lode, and in the loose head immediately above it, having excited considerable local attention, 1 shall (with your permission) give as complete an enumeration of them as I am able, though a minute and lengthy description would be equally tedious and unnecessary; as they are chiefly aqueous depositions of siliceous and aluminous matter, coloured by the oxides of iron and manganese, and do not essentially differ from otherformations of the same kind of frequent occurrence in other mining districts; for as to the statement, that precious gems, \&c. had been discovered there, that being now admitted to have originated in a mistake, no further notice need be taken of it.

Quartz-Occurs in a granular form, in corroded amorphous masses, in thin plates crossing each other at right angles (cellular quartz), stalactitic and crystallized. The crystals are all secondary, and mostly hexagonal prisms, terminated by an hexagonal pyramid; the faces generally unequal. In some the pyramid is nearly triangular, the alternate angles being deeply replaced by planes. In some the edges, either of the prism, or pyramid, or both, are bevelled; occasionally very regular prisms, terminated by a pyramid at each end, are met with, 
with, and in some specimens the prism is so shortened that the pyramids appear to be nearly joined base to base. Columnar hexagonal prisms of opaque quartz are of frequent occurrence, forming the nucleus, round which the other crystals are often clustered, or stalactitic chalcedony deposited. Of the transparent crystals, some are colourless; of the rest, the colours are ferruginous (this most common), clear topaz yellow, dark red passing into black; smoky brown (cairngorm); various shades of purple, violet, or rose-pink (amethystine quartz), and bright ruby red: these last are minute and very perfectly formed crystals, lining cellular quartz. The finest specimens of the amethystine quartz occur (very sparingly) in geodes, in the loose head; the rest are found clustered in rounded, reniform, or radiated masses, lining cavities, and investing and invested by chalcedony.

Flint-In amorphous masses, and passing into chalcedony, \&c.; the colours mostly ferruginous, or brownish black.

Chalcedony-Passing into and also investing crystallized quartz; stalactitic (this occasionally incloses distinct globules of water), mamillated, botryoidal, and lenticular. The prevailing colours, various shades of ferruginous brown passing almost into black; but oceasionally, specimens are met with of clear yellow; pure milk-white, passing into pearly and translucent white; cærulean, passing into peach-colour, and light gray; and fine plum-colour (the last from a bunch of manganese). Frequently two or three successive coatings, sometimes of the same, sometimes of distinct colours, invest each other, between each of which a thin lining of clay is often interposed; some of the white and cærulean varieties are hydrophanous; others have a very delicate coating of aluminous matter, which causes their colour to deepen considerably on the application of moisture. Pseudo-morphous crystals of this substance also occur, formed within cavities from which other crystallized substances have been by some natural cause, (probably solution,) removed. Irregular masses of siliceous matter that have obviously invested,either wholly or partially, crystals of iron-ore. Iron-pyrites, quartz or garnet, are of frequent occurrence. I have specimens of the substance in moulds of this kind, and conceive that much of (if not all) the Haytorite (as those crystals have been named) is referable to some of the different forms of the above substances, and is chalcedonic matter filling the said cavities by stalagmitic deposition; some of the faces of the crystals are very splendent, others rough; in some of the crystals all are rough: the fracture is different from that of a true crystal, nor have I ever succeeded in obtaining a regular cleavage; the crystals are of various sizes; 
the sides of the planes in some exceeding an inch, in others scarcely 1-8th of an inch. They are mostly found in a matrix of ferruginous clay, in juxta-position with massive chalcedony, quartz, and specular iron.

Semi-opal-Mostly in irregularly rounded nodules, invested by indurated clay (lithomarya). The colours, various shades of blue, green, or yellow, occasionally all passing into each other in the same specimen, or forming distinct stripes. It also frequently alternates in stripes with the indurated clay.

Garnet-Massive, blended with actinolite, \&c. in the lode, and especially at the eastern end; and crystallized, mostly in rhomboidal dodecahedrons, and their modifications. The colours, various shades of yellowish or reddish brown, passing into black minute crystals, occur (rarely) on the surface of the ore under glassy actinolite. Most of the crystals are coarse, and of inferior size.

Actinolite-Intimately blended with the ore, in amorphous masses, and in distinctly radiated clusters, the radii from 1-8th of an inch to an inch in length: the colours varying from a light to a very dark green. A thin variety, with a vitreous lustre, occurs sparingly on the surface of the ore. Actinolite is very abundant, and gives a greenish hue to a large portion of the ore. It is most prevalent in the upper and under beds, and seems to increase with the depth.

Some fine cabinet-specimens of all the above species have been found; an interesting series of which (the most complete I believe that has been formed) is in the possession of Shirley Woolmer, Esq. of Exeter.

The ore, when melted, produces iron of a very tough and superior description, as I have myself proved by some experiments. It is also stated, on good authority, to be capable of conversion into excellent steel; but the purpose to which it has hitherto been applied is that of mixing with the argillaceous ironstone of the Welch coal-measures, to improve its quality; for which, I understand, it is preferable to the hematitic ores of Lancashire; and this, I should suppose, will be the purpose that it will ultimately be found most practically available for; as its distance from proper fuel (the Bovey coal, situated within three or four miles of it, from some late experiments that have been made, giving very little hope of being efficient for the purpose of smelting, and the Dartmoor peat being at too great a distance) would probably be an effectual obstacle to the erection of any works in the neighbourbood, even supposing a less limited quantity of ore to exist, than at present appears to be the case. But this is a part of the subject on which I am incompetent to treat, and it is besides foreign to the 
Mr. Mageough's Method of mounting Thermometers. 365

object of this communication, which is to illustrate a small portion of a district, that in the circle of a few miles (taking the large clay-deposit of Bovey-heath as a centre) is perhaps, in a geological point of view, one of the most interesting districts in the kingdom. And I propose (in conjunction with J. G. Croker, Esq. of Bovey Tracey, who has for many years paid great local attention to the subject), if consistent with the plan of your Journal, to nake it the medium of two or three communications (accompanied by sections, \&c.), pointing out carefully the different strata, their extent and junction, and the lodes, as far as explored, that occur in them. To this gentleman, as well as to Mr. Petherick the superintendent of the iron-mine, I am indebted for much valuable assistance in drawing up the present paper. I remain, Gentlemen, Your most obedient servant,

Ilsington, Devon, April 9, 1828. J. T. Kingston.

LVIII. Account of a new Method of mounting Thermometers. By Mr. W. Mageovgh.

To the Editors of the Philosophical Magazine and Annals. Gentlemen,

THE following is an account of a method of mounting the 1 thermometer-tube, in order to make it applicable to purposes for which, as fitted-up at present, it could not be used.

This method has not, that I know of, been hitherto practised in making thermometers; but about two years since, the same principle was successfully applied to barometers.

Mounted in this manner, the tube may be made of earthenware or metal, as well as of glass; it may contain metals or other substances which will expand by heat; and by a little management be introduced into, and made to indicate degrees of temperature, that would speedily destroy thermometers of the ordinary construction. The present account relates only to tubes of glass, such as are generally used for making thermometers, without any other condition, than that the size be adapted to the purpose proposed to be effected by the instrument. If large enough, it will move with sufficient force to give notice when the apartment where it is placed attains a given temperature, by touching a light lever connected with the sort of alarum-machinery often put into the cheapest clocks. Or, a prepared paper maybe made to pass over a hair-pencil, charged with a liquid not liable to dry or freeze, which pencil, by means of a simple addition to the hour-movement of a common clock, 